\title{
TWO NEW SPECIES OF TAYLORIELLA (RHODOMELACEAE, RHODOPHYTA) FROM THE NORTHEASTERN NORTH PACIFIC ${ }^{1}$
}

\author{
Michael J. Wynne \\ Herbarium and Division of Biological Sciences, The University of Michigan, Ann Arbor, Michigan 48109
}

\section{ABSTRACT}

Two new species are recognized in the rhodomelacean genus Tayloriella Kylin: T. divaricata sp, noz. and T. abyssalis $s p$. noz. These two taxa are distributed in the northeastern North Pacific, the former ranging from Amchitka Island in the Aleutians through southcentral Alaska to northern British Columbia, and the latter ranging also from Amchitka Island through southcentral Alaska and British Columbia into northern Washington. A characteristic of these two species shared with the type of Tayloriella is that the abaxial lateral always overtops the monopodially developed axes in every order of branching. The laterals have little congenital fusion with the parent axes. A common feature in these two species is that the laterals are terminated in a relatively long monosiphonous portion (usually 6 or 7 cells). The relationship of Tayloriella to Pterosiphonia and Pterosiphoniella is discussed.

Key index words: North Pacific; Rhodomelaceae; Rhodophyta; Tayloriella spp. nov.

Recent studies on marine algae occurring in the upper North Pacific have revealed the presence of undescribed taxa in the red algal family Rhodomelaceae (Wynne 1980, Wynne and Norris 1982, Masuda 1982). Collections of some algae belonging to this family and sharing some distinctive characteristics have been made in Alaska (westward to Amchitka Island, the Aleutians), British Columbia, and northern Washington. These terete, uncorticated, polysiphonous algae lack vegetative trichoblasts but have ultimate branches with relatively long, monosiphonous portions. Although branch primordia are radially arranged at the apex, the branches later assume a distichous arrangement. Another feature shared by this complex of algae is that their axes are flexuous, or zig-zag in outline, the lateral branches overtopping the parent axes to give the appearance of a sympodial organization. These algae, however, are monopodially constructed. They are placed in Tayloriella (Kylin 1938), a genus characterized by most of these features.

Two new species are recognized. Tayloriella divaricata sp. nov. is known from Alaska and British Columbia. This alga consists of erect, delicate axes with 4 or 5 (rarely 6 ) pericentral cells per segment. Tetrasporangia are produced singly or in short series in swollen axes. Female plants bear cystocarps with very large carposporangia. Tayloriella abyssalis

\footnotetext{
Accepted: 2 October 1984.
}

sp. nov, is known from Alaska, British Columbia, and Washington. The axes have 5 or 6 pericentral cells per segment and consist of an erect system arising from a creeping system. Male and female/cystocarpic plants are known.

\section{MATERIALS AND METHODS}

The collections made at Amchitka Island by Lebednik, Weinmann, and Wynne were in conjunction with their involvement in contract work carried out by the Fisheries Research Institute of the University of Washington, Seattle, with the US Atomic Energy Commission [Contract No. AT(26-1)-171]. Other collections were made during the author's tenure as a summer instructor at Friday Harbor Laboratories, University of Washington. Additional collections were provided by the Herbarium of the University of British Columbia (UBC). The material was available both as herbarium specimens and as wet-preserved collections ( $5 \%$ formalin/sea-water). Specimens were observed under a Zeiss research microscope, either unstained or stained with $1 \%$ aniline blue acidified by very dilute $\mathrm{HCl}$ and then solidified with glucose (Karo) syrup. Drawings were made with a camera lucida mounted on the microscope, and photomicrographs were taken using a camera mounted on the same microscope.

\section{RESULTS}

Tayloriella divaricata sp. nov. (Figs. 1-11)

Thallus fasciculum delicatum implicatum, e filamentis erectis teretibus constitutum, et altitudinem c. $20 \mathrm{~cm}$ attingens, formans; apices initia ramorum radiatim abscindentes, ramis, autem, bilateralem dispositionem mox induentibus; rami intervallis plerumque 2 (necnon 3 vel 4 ) segmentorum enascentes; ramuli schematem axium parentium repetentes; rami laterales ultimi in cacumina monosiphonacea e 6-8 (-12) cellulis constituta desinentes; axis 75-115 $\mu \mathrm{m}$ lat.; segmenta singula in axibus vetustioribus usque ad quasi 1800 um longitudine se porrigentia; quattuor (rarius 5 vel 6) cellulae pericentrales in omni segmento visae; axes non corticati; tetrasporangia ovoidea,

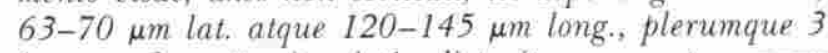
(unum vel quattuor) seriatim disposita; cum matura axem fertilem distendentia; cystocarpus pauciora carposporangia magna usque ad $180 \mu \mathrm{m}$ long, atque ad $70 \mu \mathrm{m}$ lat. contimens; plantae masculae ignotae.

Holotypus. Legit P. A. Lebednik AM293 (MICH), 26.iv.1969, Constantine Harbor (51 $24^{\prime} 48^{\prime \prime} \mathrm{N}$, $\left.179^{\circ} 18^{\prime} 00^{\prime \prime} \mathrm{E}\right)$, Amchitka Island, Aleutians, Alaska, U.S.A. Tetrasporic. Dredged from 17-27 m depth.

Thallus forming a delicate, entangled clump of erect, terete filaments, reaching about $20 \mathrm{~cm}$ height; apices cutting off branch initials in a radial manner but branches soon assuming a bilateral arrangement (Figs. 1 and 9); branches arising at intervals of usually 2 (also 3 or 4 ) segments, with very little con- 
genital fusion; ramuli repeating the pattern of the parent axes; ultimate laterals terminating in monosiphonous tips of $6-8(-12)$ cells; axes $75-115 \mu \mathrm{m}$ broad; individual segments in older axes stretching to approx. $1800 \mu \mathrm{m}$ in length; four (less commonly 5 or 6) pericentral cells per segment; axes uncorticated; tetrasporangia ovoid, $63-70 \mu \mathrm{m}$ broad and $120-145 \mu \mathrm{m}$ long, in series of commonly 3 (one to four), each associated with two elongate cover cells, when mature the sporangia distending the bearing axis (Figs. 2, 10, and 11); cystocarp with relatively few, large carposporangia (to $180 \mu \mathrm{m}$ long and to $70 \mu \mathrm{m}$ broad); male plants unknown.

Holotype. Collected by P. A. Lebednik, No. AM293, deposited in $\mathrm{MICH}$.

Isotype. Deposited in U. S. and UBC.

Additional records. ALASKA. Bluff Point, Kachemak Bay, southcentral $\left(59^{\circ} 40^{\prime} \mathrm{N}, 151^{\circ} 41^{\prime} \mathrm{W}\right)$ : 25.v.1976, legit R. J. Rosenthal (UBC A59907); tetrasporic; $13 \mathrm{~m}$ depth on rocks; entangled with Pleonosporium pedicellatum prox.; Amaknak Island, Dutch Harbor, Unalaska Bay, Aleutians ( $53^{\circ} 55^{\prime} \mathrm{N}, 166^{\circ} 36^{\prime}$ W): 8.v. 1980, legit Dennis Lees (UBC A62664); cystocarpic \& tetrasporic; $10 \mathrm{~m}$ depth. BRITISH COLUMBIA. Call Inlet, Broken Island $\left(50^{\circ} 31^{\prime} \mathrm{N}\right.$, $126^{\circ} 18^{\prime}$ W): 16 .iv. 1975 , legit 'T. F. Mumford (UBC A52911, A52938); tetrasporic; $13 \mathrm{~m}$ depth on rocks. Whale Channel, Princess Royal Island, Redfern Point $\left(53^{\circ} 03.8^{\prime} \mathrm{N}, 129^{\circ} 10.8^{\prime} \mathrm{W}\right): 26$.iii.1976, legit B. Smith (UBC A55558); cystocarpic \& tetrasporic; $13 \mathrm{~m}$ depth.

Distribution. Northern British Columbia, southcentral Alaska and the Aleutians to Amchitka Island; in sublittoral (10-27 m depth).

This alga forms matted clumps of filaments reaching $15-20 \mathrm{~cm}$ in overall extent, such as UBC A52911. Individual axes are strongly and repeatedly divaricate, giving a zig-zag appearance (Fig. 5). This divergent pattern in which branches arise means that there is minimal congenital fusion between a branch and its bearing axis (Figs. 7 and 8).

Two characteristics showing some variation in this species are the number of pericentral cells and the number of segments between consecutive branches. Four or five pericentral cells per segment are most frequently observed (Figs. 3 and 4), but six pericentral cells may also occur. This variability can be present in a single thallus and is seen in sterile material, thus not simply a result of the two cover cells associated with a tetrasporangium. Likewise, the sequence of segments between adjacent laterals is variable in a single specimen. Branches arise at intervals of 2,3 , or 4 segments, the smaller number of segments being more common in upper parts of the plants (Figs. 1, 7, and 9).

Tayloriella abyssalis sp. now. (Figs. 12-23)

Thallus a systemate repente axium teretium ad substratum rhizoideis affixorum, atque e systemate erecto axium teretium ramosissimorum 3-5 cm alt. constitutus; rami ad apices radiatim abscissi, dispositio bilateralis, autem, ramorum postea efficitur; rami intervallis 3 ( $r a-$ rius 2 vel 4) segmentorum reperti; rami schematem axis parentis repetentes; ordo ramorum ultimus in cacumina monosiphonacea 5-6 (-9) cellulis longitudine desinens; axes non corticati, (5) 6 (7) cellulas pericentrales omni in segmento habentes; axes 90-115 $\mu$ m lat.; segmentum rami basale dimidio inferiore segmenti admodum super segmentum ferens coniungescens; ramuli spermatangiales spiraliter procreati, uno in omni segmento, 220-250 $\mathrm{\mu m}$ (-315) $\mu \mathrm{m}$ long., duabus cellulis pedicellaribus atque distalibus 4-5 (-6) cellulis sterilibus inclusis; massa vera spermatangialis 85-95 $\mu \mathrm{m}$ long. atque 38-52 $\mu \mathrm{m}$ lat.; procarpi in segmento secundo trichoblastarum procreati; cystocarpi 158-170 $\mu \mathrm{m}$ lat., 190-208 $\mu \mathrm{m}$ alt., breviter pedicellati; tetrasporangia ignota.

Holotypus. Legit C. Tanner \& M. Hawkes (UBC A54681), 26.iii.1976, east side of York Point (53 $\left.0.5 .6^{\prime} \mathrm{N}, 129^{\circ} 10.3^{\prime} \mathrm{W}\right)$, Gil Island, Whale Channel, British Columbia, Canada. Male. $27 \mathrm{~m}$ depth.

Thallus consisting of a creeping system of terete axes attached by rhizoids to substrate and an erect system of much branched, terete axes $3-5 \mathrm{~cm}$ high; branches at apices cut off radially (Figs. 12 and 13), but a bilateral arrangement of branches is later brought about; branches occurring at intervals of 3 (less often 2 or 4) segments; branches repeating pattern of parent axis; final order of branches terminating in monosiphonous tips 5-6(-9) cells in length; axes uncorticated, with (5) 6 (7) pericentral cells per segment (Figs. 19 and 20); axes $90-115 \mu \mathrm{m}$ broad; basal segment of branch fused with lower half of segment immediately above the bearing segment; spermatangial branchlets spirally produced (Figs. 14 and 23), one per segment, 220-250 (-315) $\mu \mathrm{m}$ long, including two pedicel cells and distal $4-5(-6)$ sterile cells; actual spermatangial mass $85-95 \mu \mathrm{m}$ long and $38-42 \mu \mathrm{m}$ broad; procarps produced on second segment of trichoblasts (Fig. 22); cystocarps 158-170 $\mu \mathrm{m}$ broad, 190-208 $\mu \mathrm{m}$ tall, briefly pedicellate (Fig. $15)$; tetrasporangia unknown.

Holotype. Collected by C. Tanner and M. Hawkes; deposited in UBC (A54681).

Additional records. ALASKA. Constantine Harbor dock ( $\left.51^{\circ} 24^{\prime} 35^{\prime \prime} \mathrm{N}, 179^{\circ} 17^{\prime} 42^{\prime \prime} \mathrm{E}\right)$, Amchitka Island, Aleutians: 13.viii.1970, legit P. A. Lebednik \& M. J. Wynne (Wynne 3044, MICH), sterile, to $10 \mathrm{~m}$ depth on settling surfaces and ropes; 9.ix.1967, legit K. Kimura (Weinmann 21, MICH), sterile, on shells at $13 \mathrm{~m}$ depth; 13.iv.1969, legit P. A. Lebednik AM264 $(\mathrm{MICH})$, sterile, on cobble at $13 \mathrm{~m}$ depth. Prince William Sound, Naked Island, Bass Harbor, $1 \mathrm{~km}$ north of West Point: 2.viii.1979, legit D. Lees 147 (UBC A61380), sterile, $10 \mathrm{~m}$ depth. BRITISH COLUMBIA. North end of Campania Island, east end of Sharp Bay $\left(53^{\circ} 10.6^{\prime} \mathrm{N}, 129^{\circ} 32.5^{\prime} \mathrm{W}\right)$ : 5.iii.1976, legit C. Tanner and M. Hawkes (UBC A54542), female/cystocarpic, $13 \mathrm{~m}$ depth. WASHINGTON. San Juan County, San Juan Island., Lime Kiln Light $\left(48^{\circ} 31.5^{\prime} \mathrm{N}, 123^{\circ} 10^{\prime} \mathrm{W}\right): 18, v i i .1978$, legit M. J. 


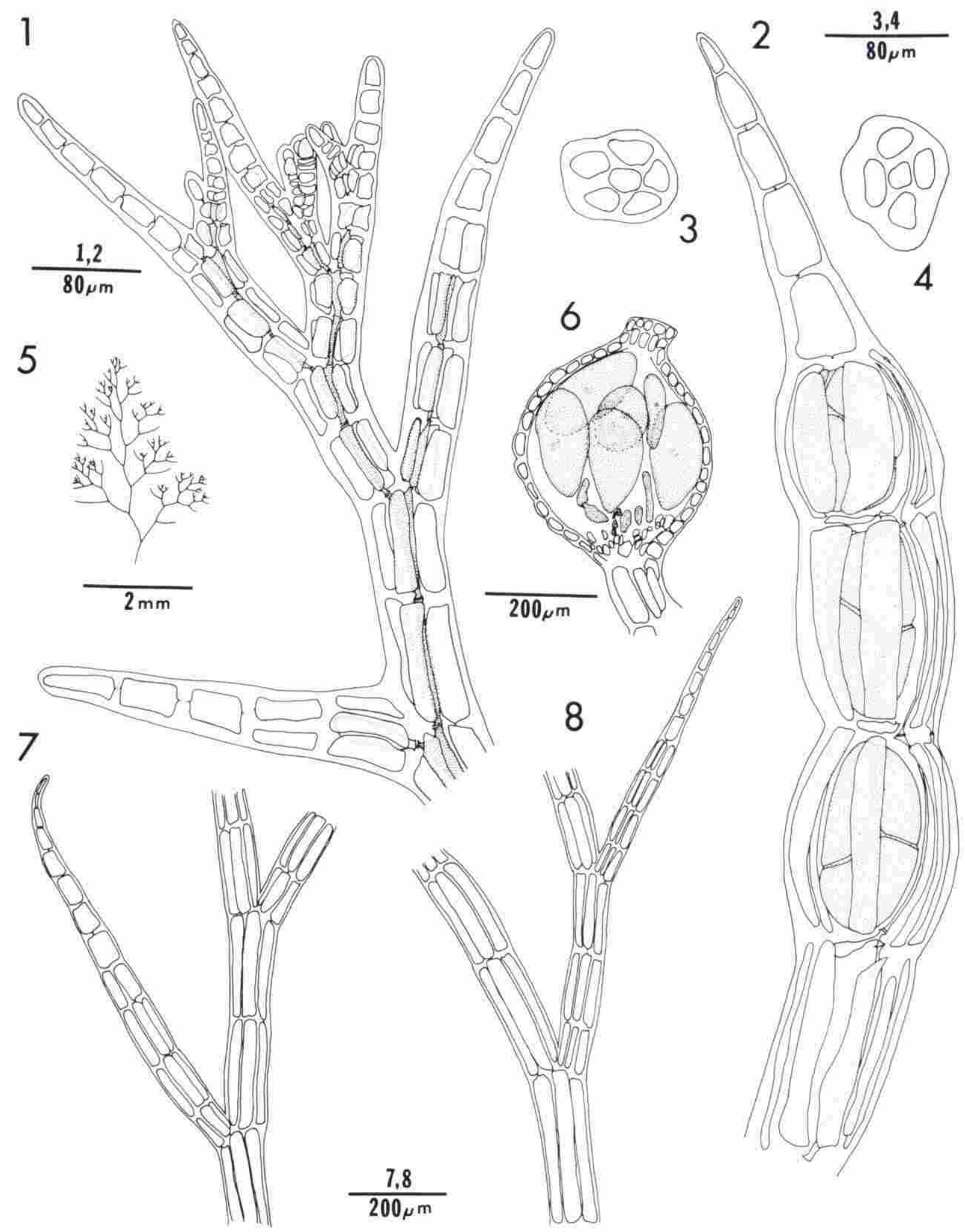

Fics. 1-8. Tayloriella divaricata $\mathrm{sp}$. nov. Fig. 1. Apex with radially arranged laterals. FiG. 2. Axis bearing a series of tetrasporangia. Fics. 3 and 4. Axes in cross-section, showing axial cell and pericentral cells. Fig. 5. Detail of habit, showing divaricate nature of branching. Fig. 6. Cystocarp in optical section. Figs. 7 and 8 . Portions of axes bearing laterals. 


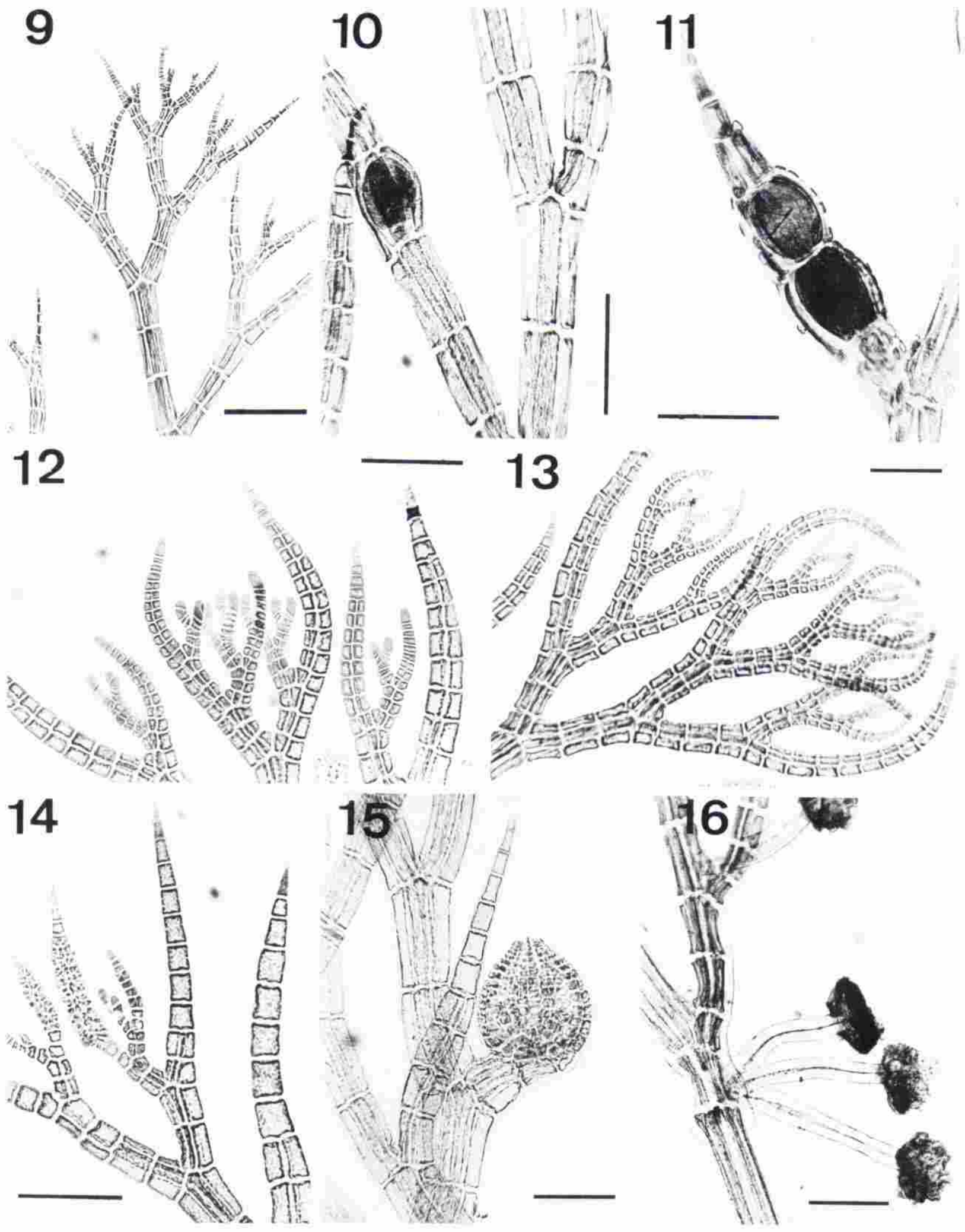

Figs. 9-16. Figs, 9-11. Tayloriella dizaricata sp. nov. Figs. 12-16. Tayloriella abyssalis sp. nov. Fic. 9. Apical region with typical flexuous axes (UBC A59907). Fig. 10. Tetrasporic axes, with a single tetrasporangium (UBC A59907). FiG, 11. Tetrasporic axis, with a pair of tetrasporangia (UBC A59907). FiG. 12. Apical region (UBC A54681). Fig. 13. Apical region (MW 4922). FiG. 14. Early development of spermatangial cluster (UBC A54681). FiG. 15. Young cystocarp (UBC A54542). FiG, 16. Production of rhizoids and laterals from the same segment (MW 3044), Scale $=100 \mu \mathrm{m}$ in Figs. 9-11, 15, 16. Scale $=50 \mu \mathrm{m}$ in Figs. $12-14$. 
Wynne 4922 (MICH), sterile, lowest eulittoral on limestone. Hein Bank, in Strait of Juan de Fuca south of San Juan I. $\left(48^{\circ} 21^{\prime} \mathrm{N}, 123^{\circ} 02^{\prime}\right.$ W): 27.vi.1978, legit M. J. Wynne $4809(\mathrm{MICH})$, sterile, dredged from $13 \mathrm{~m}$ depth.

Distribution. Northern Washington, British Columbia, and Alaska (Prince William Sound westward to Amchitka Island, Aleutians); typically in sublittoral, with single collection in lowest littoral.

Many of the collections of Tayloriella abyssalis were found with extensive creeping portions. A distinctive feature that helped recognize that such disjunct collections as those from the Aleutians and those in Puget Sound apparently belonged to the same species is that the creeping axes frequently produce rhizoids from the same segments that give rise to lateral branches (Fig. 16) and these rhizoids often arise in pairs. The lateral branch is located at the distal end of the segment, and the $2(1-3)$ rhizoids are located at the proximal end of the same segment. Each of the rhizoids arises from separate pericentral cells, and they are not separated by a wall from the pericentral cells.

One difference from Tayloriella divaricata is that the lateral branches show less divergence from the bearing axis. Usually the basal segment of a branch is congenitally fused along its length to the segment immediately distal to the bearing segment of the parent axis (Fig. 21). The resulting aspect is not the strongly divaricate pattern so characteristic of the other species (compare Fig. 9 with Fig. 17).

\section{DISCUSSION}

The flexuous appearance of these algae gives the impression of sympodial growth. Parsons (1975) has provided a useful insight for distinguishing monopodial and sympodial growth. In sympodial growth the youngest lateral initial being cut off from the subapical cell arises diametrically opposite the expected position of the next lateral branch because the old apical cell is shifted into the position of the next lateral. For the two new species, however, branch primordia appear as a slight bulge on the subapical cell, and then that bulge is cut off as a branch initial in the expected position to become the next lateral branch (Fig. 18), characteristic of monopodial growth.

Tayloriella was established by Kylin (1938) to include uncorticated, terete, polysiphonous algae, lacking vegetative trichoblasts and cutting off lateral branches at intervals of 2-3 segments, and these branches subsequently become bilaterally arranged. Because of the strong overtopping of parent axes by laterals, the South African type of the genus, $T$. tenebrosa (Harv.) Kyl.,, was described by Falkenberg (1901, as Streblocladia fasciculifera) as being sympodially organized. But Kylin (1938) analyzed the manner in which segment cells are cut off and the origin of laterals, and he recognized that the alga was in reality monopodially organized. The false sympodial appearance in this alga was simply the result of the laterals shifting back and forth, overtopping the parent axis. Such an organization is essentially the same as in these two taxa from the northeastern North Pacific and is a reason for their being assigned to Tayloriella rather than to Pterosiphonia.

Kylin (1956) placed Tayloriella in the Polysiphonia Group and stated that it differed from Polysiphonia in the lack of vegetative trichoblasts and the fact that laterals arise at intervals of two or three segments. In addition to the type, two other species, both Pacific Mexican, have been transferred to Tayloriella (Kylin 1956, Dawson 1963). All three species have a relatively high number of pericentral cells, namely, 8-13. An additional fact is that in the known species of Tayloriella the polysiphonous condition is present within two or three segments of the apical cell. This is not true for the two new species.

These two species of Tayloriella have been mistaken for species of Pterosiphonia. The holotype of $T$. abyssalis had been originally identified as $P$. gardneri Hollenb. [= P. hamata Sinova; cf. Wynne (1985)] in Hawkes et al. (1978), and another collection of T. abyssalis (UBC A61380) had been identified as $P$. bipinnata (Post. \& Rupr.) Falkenb. This possibility for confusion necessitates bringing Pterosiphonia into the discussion.

Pterosiphonia, as typified by P. cloiophylla (C. Ag.) Falkenb., is characterized by bilateral alternate-distichous branching (Hommersand 1963) and congenital fusion between the basal parts of lateral branches and the bearing axis (Ardré 1967). The extent of congenital fusion between the lateral branch and the parent axis may be relatively limited, as the one and a half segments in P. pennata (C. Ag.) Falkenb., or more extensive, as the five segments in P. complanata (Clem.) Falkenb. (Ardré 1970, Hommersand 1963). In contrast to the condition in Pterosiphonia, this congenital fusion is minimally developed in Tayloriella. In Tayloriella tenebrosa Kylin (1938) reported that the branch primordia are arranged in a left-hand spiral with a divergence of $2 /$ 5 , but these laterals tend to become bilaterally arranged away from the apex. In their very earliest stages the laterals of the erect axes in Pterosiphonia have been shown to lie in a single plane (Hommersand 1963,p. 265, Ardré 1967, p. 39). In male plants in Pterosiphonia, however, there is a shift from the usual alternate-distichous pattern to a spiral arrangement of spermatangial branches from every segment (Suneson 1940, Hommersand 1963).

A relatively large number of species of Pterosiphonia have been reported to be present in the North Pacific. The following species are known only from the eastern North Pacific: $P$, baileyi (Harv.) Falkenb., P. dendroidea (Mont.) Falkenb., P. farlowii Hollenb., $P$. gracilis Kyl., and $P$. spinifera (Kütz.) Ardré var. robusta Ardré (Ardré 1967, Widdowson 1975, Abbott and Hollenberg 1976, Hollenberg 1976). Pterosiphonia fibrillosa Okam. and $P$. japonica Nagai are 


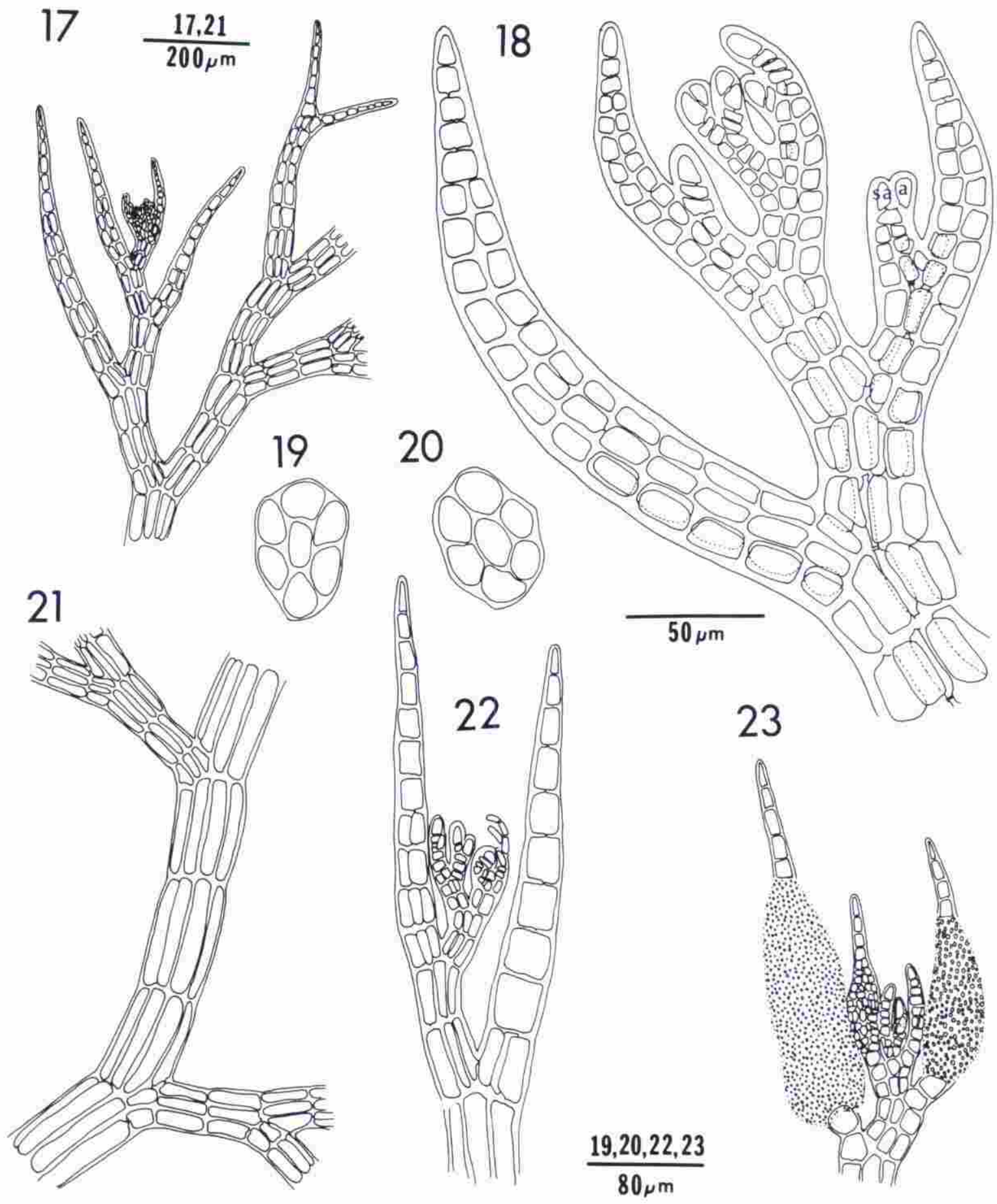

Figs. 17-23. Tayloriella abyssalis sp. nov. Fig, 17. Apical region of axes with radially arranged laterals. Fic. 18. Detailed aspect of apex of thallus, showing monopodial growth at primary apex and also at the apex of a lateral branch. $a$, apical cell; $s a$, subapical cell. Figs. 19 and 20. Axes in cross-section, showing axial cell and pericentral cells. Fic. 21. Portion of axis bearing laterals. FiG. 22. Apical region of female plant with a procarp borne on the second segment of a trichoblast. Fic. 23. Spermatangial clusters borne in a radial arrangement.

known only from the western North Pacific, whereas $P$. bipinnata, $P$. hamata, and $P$. pennata are known from both the eastern and western North Pacific.

Most of the known North Pacific species of Pter- osiphonia can be eliminated from consideration on the basis of one or more of the following traits: higher number of pericentral cells; well developed cortication of the axes; polysiphonous condition es- 
tablished within 2 or 3 segments of the apical cell of a lateral; and an alternate-distichous branching pattern occurring at the apex.

Pterosiphonia hamata, a species with 6 or 7 pericentral cells per segment and uncorticated axes, has been recorded from the same approximate range as the ranges of the two new species (Setchell and Gardner 1903, as $P$. arctica, Hollenberg 1969, as $P$. gardneri; see also Sinova 1940), namely, the Aleutians eastward and southward to northern Washington. But that species has apices with an alternate-distichous branching pattern coarse axes, a polysiphonous condition commencing close to the apices, and conforms well to Pterosiphonia. Pterosiphonia bipinnata also has uncorticated axes that can be delicate, but the pericentral cell number of that species ranges from 11 to 18 (Falkenberg 1901, Abbott and Hollenberg 1976).

Three species of Pterosiphonia were described by Levring (1941) from Juan Fernandez Island west of Chile, all three species with only 4 pericentral cells per segment. Two of these species $(P$. pusilla and $P$. skottsbergii) have minimal congenital fusion of the laterals with the parent axis, which is a point of agreement with the two new species of Tayloriella. The creeping axes of $P$. pusilla produce rhizoids extensively, sometimes in clusters, resembling the situation in $T$. abyssalis. The axes of $P$. pusilla, however, become corticated and are strongly percurrent with no overtopping of the primary axis by the laterals. The axes of $P$. skottsbergii also have strongly percurrent axes and bear usually simple laterals. These species of Levring thus can be discounted from our consideration of the North Pacific species.

Although the significance of this character is not fully evaluated, a difference in the formation of rhizoids in Pterosiphonia and Tayloriella abyssalis can be noted. Rhizoids are produced from the proximal ends of the segments in T, abyssalis (Fig. 16), whereas they are produced from the distal ends of segments in several species of Pterosiphonia ( $P$. pennata, $P$. spinifera, and $P$. parasitica) (Ardré, in litt.) as well as in the related genus Symphiocladia (Ardré 1973-1974).

To further elucidate some of the problems in the delimitation of some of the genera in the Rhodomelaceae, a discussion of Pterosiphoniella Dawson (1963) is pertinent. Dawson did not know whether to place his genus with the radially organized Polysiphonia group or with the bilaterally organized Pterosiphonia group of Kylin (1956) because it had both the vegetative trichoblasts and a bilateral habit achieved after an initial radial organization. In this latter characteristic along with its ecorticate axes Dawson's species agrees with the two new species under discussion. But the fact that the Mexican alga has usually $8(10-16)$ pericentral cells and flattened axes distinguishes it from the new species of Tayloriella. Vegetative trichoblasts are reportedly of rare occurrence in Pterosiphonia, e.g. in P. pennata (Williams 1948, Lauret 1967, Ardré 1967) and in $P$. fibrillosa (Okamura 1912). This fact suggests that Dawson's Pterosiphoniella may not be based on a substantial difference to separate it from Pterosiphonia.

In conclusion, it is evident that the two new taxa from the northeastern North Pacific are best assigned to the genus Tayloriella because of their production of uncorticated, polysiphonous axes at intervals of 2-3 segments, each parent axis being overtopped by the abaxially placed lateral, the initial radial organization being converted into a bilateral arrangement of branches away from the apex, and the minimal degree of congenital fusion between laterals and the parent axes. This suite of traits distinguish these algae from members of Pterosiphonia. The lack of vegetative trichoblasts in the two newly described species separate them from Pterosiphoniella.

The author gratefully acknowledges the advice given by Drs. F. Ardré, M. Hommersand, and M. Parsons. He also wishes to thank Dr. R. F. Scagel for the loan of specimens from the Herbarium of the University of British Columbia. Dr. Hannah Croasdale kindly provided the Latin descriptions.

Abbott, 1. A. \& Hollenberg, G. J. 1976. Marine Algae of California. Stanford University Press, Stanford, California, xii + [1]+ $827 \mathrm{pp}$.

Ardré, F. 1967. Remarques sur la structure des Pterosiphonia (Rhodomélacées, Céramiales) et leurs rapports systématiques avec les Polysiphonia. Rev. Algol., N.S. 9:37-77.

1970. Contribution à l'étude des algues marines du Portugal. 1-La flore, Portugaliae Acta Biologica (B) 10:1-423, 56 pls.

- 1973-1974. Remarques sur la structure et les affinités des Symphiocladia (Rhodomélacées, Céramiales). Botaniste 56: $19-54$.

Dawson, E. Y. 1963. Marine red algae of Pacific Mexico. Part 8. Ceramiales: Dasyaceae, Rhodomelaceae. Nova Hedw. 6: $401-81,46$ pls.

Falkenberg, P. 1901. (Reprinted 1978) Die Rhodomelaceen des Golfes von Neapel .... Fauna Flora Golfes Neapel 26. Berlin, xvi +754 pp., 24 pls. (Re-issued by O. Koeltz Sc. Publ., Koenigstein, West Germany.)

Hawkes, M. W., Tanner, C. E. \& Lebednik, P. A. 1978. The benthic marine algae of northern British Columbia. Syesis 11: 81-115.

Hollenberg, G. J. 1969. New species of marine algae from Washington, U.S.A. Syesis 2:163-9.

- 1976. Correction of algal binomial. Taxon 25:122.

Hommersand, M. H. 1963. The morphology and classification of some Ceramiaceae and Rhodomelaceae. Univ, Calif. Publ. Bot. 35:165-366.

Kylin, H. 1938. Verzeichnis einiger Rhodophyceen von Südafrika. Lunds Univ. Ársskr. N. F., Avd. 2, 34(8), 26 pp., 8 pls. - 1956. Die Gattungen der Rhodophyceen. CWK Gleerup, Lund, $x v+673 \mathrm{pp}$,

Lauret, M. 1967. Présence de trichoblastes végétatifs chez Pterosiphonia pennata (Roth) Falkenberg. C. R. Acad. Sci. Paris 265:1901-4.

Levring, T. 1941. Die Meeresalgen der Juan Fernandez-Inseln. In Skottsberg, C. [Ed.] The Natural History of Juan Fernandez Island. Vol. II, Almqvist \& Wiksells. Uppsala, pp. 601-670, pls. 49-53.

Masuda, M. 1982. A systematic study of the tribe Rhodomeleae (Rhodomelaceae, Rhodophyta). J. Fac. Sc., Hokkaido Univ., Ser. V, 12:209-400, 28 pls.

Okamura, K. 1912. Icones of Japanese Algae. Vol. 2, No. 10. Kazamoshoba, Tokyo. 
Parsons, M. J. 1975. Morphology and taxonomy of the Dasyaceae and the Lophothalieae (Rhodomelaceae) of the Rhodophyta. Aust. J. Bot. 23:549-713.

Setchell, W. A. \& Gardner, N. L. 1903. Algae of northwestern America. Uniz. Calif. Publ. Bot. 1:165-418.

Sinova, E. S. 1940. The algae of the Commander Islands. Trans. Pacif. Comm. Acad. Sc. U.S.S.R. 5:165-243 [In Russian].

Suneson, S. 1940. Studies on the structure and the reproduction of Pterosiphonia parasitica. Sv. Bot. Tidskr. 34:315-33.

Widdowson, T. B. 1975 ("1974"). The marine algae of British Columbia and northern Washington: revised list and keys. Part II. Rhodophyceae (red algae). Syesis 7:143-86.
Williams, L, G, 1948. Seasonal alternation of marine floras at Cape Lookout, North Carolina. Am. J. Bot. 35:682-95.

Wynne, M. J. 1980. Beringiella (Rhodomelaceae, Ceramiales), a new red algal genus from Alaska. Contr. Univ. Mich. Herb. 14: $221-9$.

1985. Records and notes on Alaskan marine algae. Syesis (In press).

Wynne, M. J. \& Norris, R. E. 1982. Schizochlaenion gen. nov. (Rhodomelaceae, Ceramiales), a new red algal genus from the north-eastern North Pacific. Phycologia 21:288-98.

\title{
ULTRASTRUCTURE OF THE FLAGELLA OF THE COLORLESS PHAGOTROPH PERANEMA TRICHOPHORUM (EUGLENOPHYCEAE). I. FLAGELLAR MASTIGONEMES'
}

\author{
Lula L. Hilenski and Patricia L. Walne ${ }^{2}$ \\ Department of Botany, University of Tennessee, Knoxville, Tennessee 37996-1100
}

\section{ABSTRACT}

The organization of two types of nontubular mastigonemes associated with the anterior flagellar surface of the phagotrophic biflagellate Peranema trichophorum (Ehrenberg) Stein is described from studies of thin sections, negative-stained and shadow-cast preparations of both intact and isolated, detergent-treated flagella. Long mastigonemes form a unilateral, spiral array of tufts which curve toward the distal end of the flagellum, while two short mastigoneme ribbons form unequal halves of a bilateral array parallel to the flagellar long axis. Each ribbon is composed of individual overlapping fan-shaped tiers of short mastigonemes interlinked by fine fibrils. A model proposed for Peranema mastigonemes is similar to recent models of mastigoneme organization in Euglena.

Key index words: euglenoid; flagella; mastigonemes; Peranema

Associated with the flagellar surface of many algae and protozoans are elaborate hair-like appendages or mastigonemes. Although mastigonemes from different taxa vary in structure, they can be broadly categorized as tubular (e.g. Ochromonas), nontubular (e.g. Euglena) or striated (e.g. Chlamydomonas and some prasinophycean algae) (reviewed by Bouck 1972). The proposed function of the stiff "oar-like" tubular mastigonemes is to reverse the thrust of the flagellum; the presumptive flexibility of nontubular mastigonemes allows them to wrap around the flagellum, thus increasing both its surface area and the efficiency of propulsion (Jahn and Bovee 1968, Bouck 1972). Earlier research on mastigonemes focused on the obvious questions concerning structural ar-

\footnotetext{
Accepled: 11 October 1984

${ }^{2}$ Address for reprints.
}

rangement and function in motility. More recently biochemical studies have shown that the nontubular mastigonemes on the emergent flagellum of Euglena are complex glycoproteins (Bouck et al. 1978, Bouck and Rogalski 1982). Because these glycoproteins are confined to that domain of the plasma membrane surrounding the flagellum, the study of flagellar mastigonemes offers opportunities to examine broader aspects of membrane dynamics, including the synthesis, assembly, insertion and attachment of membrane components.

We here describe the organization of the two types of nontubular mastigonemes on the conspicuous anterior flagellum of the colorless phagotrophic euglenoid Peranema and propose a model for mastigonemal organization in this organism; we also compare our results with recent models of flagellar organization in Euglena (Bouck et al. 1978, Bouck and Rogalski 1982, Hyams 1982, Melkonian et al. 1982).

\section{MATERIALS AND METHODS}

Cultures of Peranema trichophorum (Ehrenberg) Stein (No. $1260 / 1)$ were obtained from The Culture Centre of Algae and Protozoa, Cambridge, England. Cells were maintained on an undefined medium containing milk and calcium sulfate (Chen 1950) at $20^{\circ} \mathrm{C}$ on a $16: 8 \mathrm{LD}$ cycle with fluorescent illumination of 300 $\mu \mathrm{W} / \mathrm{cm}^{2}$.

\section{TEM}

For transmission electron microscopy, specimens were usually fixed for $30 \mathrm{~min}$ at $0-4^{\circ} \mathrm{C}$ in a $1: 1$ mixture of $2 \%(\mathrm{v} / \mathrm{v})$ glutaraldehyde and $2 \%(\mathrm{w} / \mathrm{v}) \mathrm{OsO}_{4}$ buffered in cold $0.05 \mathrm{M}$ sodium cacodylate, $\mathrm{pH} 7.0$, and postfixed in $2 \%(\mathrm{w} / \mathrm{v}) \mathrm{OsO}_{4}$ buffered in $0.1 \mathrm{M}$ sodium cacodylate, $\mathrm{pH} 7,0$, for $3 \mathrm{~h}$ at $0-4^{\circ} \mathrm{C}$ (Franke et al, 1969). For ruthenium red (RR) localization, cells were fixed in $2 \%(\mathrm{v} / \mathrm{v})$ glutaraldehyde buffered in $0.05 \mathrm{M}$ sodium cacodylate with $0.1 \%$ (w/v) RR (ICN Pharmaceuticals, Inc.), $\mathrm{pH} 7.2$, for 1 $\mathrm{h}$ at room temperature (Luft 1971), followed by postfixation in 
This document is a scanned copy of a printed document. No warranty is given about the accuracy of the copy. Users should refer to the original published version of the material. 